\title{
Does Fascin Expression in Diffuse Large B-Cell Lymphomas have a Clinical Impact in Patients Treated with Anthracyclin-Based Chemotherapy Plus Rituximab?
}

\author{
Nazım E. KOCER ${ }^{1}$, Fatih KOSE ${ }^{2}$, Fazilet KAYASELCUK ${ }^{1}$, Ayberk BESEN ${ }^{3}$, \\ Huseyin MERTSOYLU ${ }^{3}$, Ozgur OZYILKAN ${ }^{3}$, Ilhan TUNCER ${ }^{1}$ \\ ${ }^{1}$ Baskent University Adana Research and Medical Center, Department of Pathology, Adana \\ ${ }^{2}$ Sanliurfa Research and Education Hospital, Department of Oncology, Sanliurfa \\ ${ }^{3}$ Baskent University Adana Research and Medical Center, Department of Medical Oncology, Adana, TURKEY
}

\begin{abstract}
Fascin is an actin-bundling protein that is expressed by dendritic cells of the lymphoid tissue. Fascin expression is also seen in the neoplastic cells of classical Hodgkin lymphomas, nearly half of the anaplastic lymphomas and in some diffuse large B-cell lymphomas. We aimed to investigate the clinical significance of fascin expression in CD20 positive diffuse large B-cell lymphomas (DLBCL) in patients treated with cyclophosphamide, doxorubicin, vincristine, and prednisolone plus rituximab (R-CHOP). Thirtyfour of the 55 patients included in the study showed fascin expression, 16 of them being diffuse and strong. There was no statistically significant correlation between fascin expression and overall survival and disease-free survival, sex, disease stage, chemotherapy response, whether or not having bulky disease, extranodal involvement, and international prognostic index (IPI) score. The study has failed to show prognostic significance of fascin expression in DLBCL patients treated with R-CHOP. However, because of the alterations in fascin expression in a variety of benign and malignant lymphoid entities, regardless of its prognostic impact, studies on fascin expression may help us to understand tumor biology of lymphomas better.
\end{abstract}

Keywords: Fascin, Non-Hodgkin lymphoma, Prognosis

\section{ÖZET}

Antrasiklin Temelli Kemoterapi ile Birlikte Rituksimab Tedavisi Alan Diffüz Büyük B-Hücreli Lenfoma Olgularında Fascin Ekspresyonunun Klinik Önemi Var mı?

Fascin, lenfoid dokunun dendritik hücreleri tarafından eksprese edilen, aktin paketleyici bir proteindir. Klasik Hodgkin lenfomaların neoplastik hücrelerinin, anaplastik lenfomaların yaklaşık yarıının ve diffüz büyük B-hücreli lenfomaların bir kısmının da fascin eksprese ettiği gösterilmiştir. Bu çalışmanın amacı, siklofosfamid, doksorubisin, vinkristin, prednizolon ile birlikte rituksimab (R-CHOP) tedavisi alan CD20 pozitif diffüz büyük B-hücreli lenfomalı (DBBHL) hastalarda fascin ekspresyonunun klinik önemi olup olmadığını ortaya koymaktır. Çalışmaya dahil edilen 55 hastaya ait tümör örneklerinin 34'ünde immünhistokimyasal yöntemle fascin pozitifliği saptandı. Otuzdört vakanın 16'sındaki pozitiflik yaygın ve kuvvetli idi. İstatistiksel değerlendirmede fascin ekspresyonu ile toplam yaşam süresi, hastalıksız yaşam süresi, cinsiyet, hastalı̆ın evresi, kemoterapiye yanıt, bulky hastalık olup olmaması, ekstranodal tutulum ve enternasyonal prognostik indeks (IPI) skoru arasında anlamlı bir ilişki saptanmadı. Çalışmada R-CHOP tedavisi alan DBBHL'Iı hastalarda fascin ekspresyonun prognostik önemi olduğuna dair bulgu saptanmamıştır. Farkı benign ve malign lenfoid antitelerde fascin ekspresyonunda bildirilen değişiklikler ve aynı hastalığa sahip hastalarda saptanan ekspresyon farkllıkları, prognostik önemi olmasa da, fascin üzerine yapılacak çalışmaların lenfomaların tümör biyolojisini daha iyi anlamamıza yardımcı olacağını düşündürmektedir.

Anahtar Kelimeler: Fascin, Non-Hodgkin lenfoma, Prognoz 


\section{INTRODUCTION}

Fascin is an actin-bundling protein that is expressed by dendritic cells of the lymphoid tissue. ${ }^{1}$ Although it has been once proposed as a specific marker for Reed-Sternberg cells and variants in classical Hodgkin lymphoma, it is now known that some of the diffuse large B-cell lymphomas (DLBCL) and nearly half of the anaplastic large cell lymphomas show fascin expression. ${ }^{2,3,45}$ Patients with DLBCL, the largest subtype of non-Hodgkin lymphomas, show widely variable clinical outcomes. ${ }^{6}$ So it is important to investigate markers that may have a potential prognostic impact on the clinical course of the disease for a better management of the patients. There are only few studies regarding the fascin expression in DLBCL and there is no data in the literature whether fascin expression in DLBCLs have a clinical impact or not.

The clinical applicability of a prognostic factor may depend on the specific therapy that the patient receiving $^{7}$, so we aimed to investigate the clinical significance of fascin expression in CD20 positive diffuse large B-cell lymphomas in patients treated with cyclophosphamide, doxorubicin, vincristine, and prednisolone (CHOP) plus rituximab (R), the current standard regimen for DLBCL.

\section{PATIENTS AND METHODS}

Slides taken from the representative blocks belonging to the fiftyfive patients who were diagnosed as CD20 positive DLBCL between 2005 and 2010 at the Baskent University, were immunohistochemically stained with fascin monoclonal antigen (clone 55K-2, DAKO, Carpinteria, Ca, USA) in Dako Autostainer Link48. Slides were scored semi quantitatively regarding the strength of the cytoplasmic staining (0: no staining, + :weak staining, ++ : moderate staining, +++: strong staining) and the percentage of tumor showing fascin expression (no staining, staining in $<25 \%$ of tumor, staining in $25-50 \%$ of tumor, staining in $>50 \%$ of tumor).

All results are presented as rate for categorical valuesor mean and median for continuous variables. Overall survival (OS) was determined as time between histological diagnosis and death. Disease free survival (DFS) was determined as time between histological diagnosis and relapse. Survival curves were estimated according to the Kaplan-Meier method and log-rank tests were used for univariate statistical comparisons. Fisher's exact chi-square test was also used for the statistical analysis of cathegorical values.Adjusted hazard ratios (HRs) and 95\% confidence intervals (95\% CIs) were used for estimation. All data were analyzed using SPSS 11.1 statistical package program and a $p$ value of $<0.05$ was considered statistically significant.

\section{RESULTS}

\section{Patients}

Median age of patients was 56 years (range 24-85). Thirty six $(65.5 \%)$ were male and $19(31.7 \%)$ patients were female. Six patients (10.9\%), 11 patients (20\%), 20 patients $(36.4 \%)$, and 18 patients (32.7\%) were staged as stage I, II, III, and IV at the time of diagnosis, respectively. Twenty two patients $(40 \%)$ had bulky disease and 44 patients $(80 \%)$ had extranodal involvement. ECOG performance status of patients were; 0 in 25 patients (45.5\%), 1 in 6 patients (10.9\%), 2 in 15 patients (27.3\%), and 3 in 9 patients (16.4\%). All of the patients were treated with rituximab containing regimen initially. The median overall survival was 48 months (Table 1).

\section{Immunohistochemical Studies}

Total 35 of 55 cases $(61.8 \%)$ showed positive staining with in fascin different strength and percentages of the tumors (Figure 1 and 2), while 20 of the cases were negative (Figure 3). Cases according to the stained percentage of the tumor and strength of staining were; staining in $<25 \%$ of tumor cells: 1 case $(+), 1$ case $(++), 3$ cases $(+++)$, staining in $25-$ $50 \%$ of tumor cells: 1 case (+), 2 cases $(++), 6$ cases $(+++)$, staining in $>50 \%$ of tumor cells: 1 case $(+), 3$ cases $(++), 16$ cases $(+++)$.

\section{Statistical Analysis}

Sex, ECOG performance status, stage, whether or not having bulky disease, response to initial chemotherapy and IPI score showed statistically significant effect on overall survival in univariate analyses $(\mathrm{p}=0.015, \mathrm{p}=0.043, \mathrm{p}=0.010, \mathrm{p}=0.035, \mathrm{p}<$ 0.0001 , and $\mathrm{p}=0.006$, respectively) (Table 1 ). The median disease-free survival was 23 months. None 


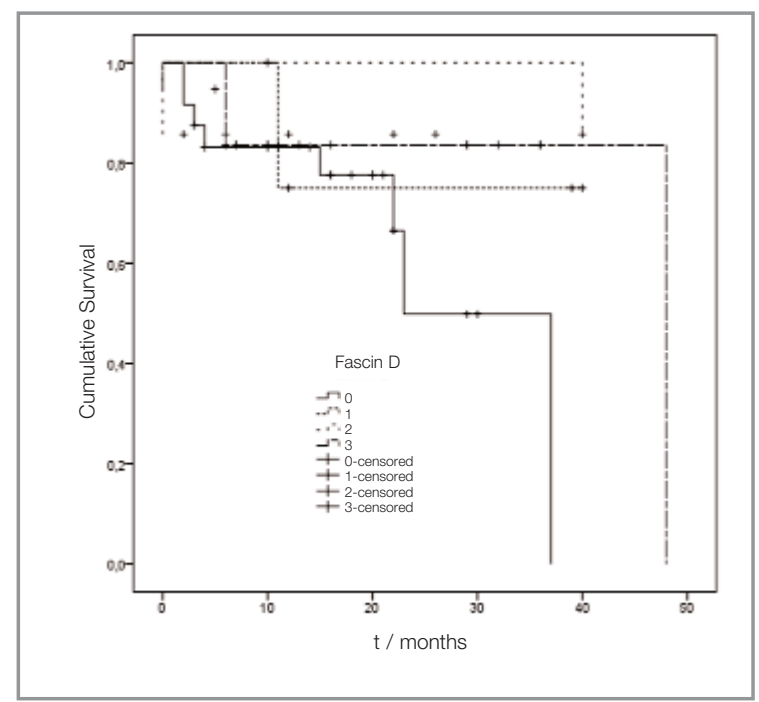

Figure 4. Graph showing relationship between fascin expression and survival $(p=0.058)$

whether or not having bulky disease, extranodal involvement, and IPI score) showed statistically significant correlation either with the strength of fascin expression or the percentage of tumor showing fascin expression ( $\mathrm{p}>0.05)$ (Figure 4,5).

\section{DISCUSSION}

Fascin is expressed in the germinal center dendritic cells of the normal lymphoid tissue. Alterations in fascin expression were reported in neoplastic follicles of follicular B-cell lymphomas as well as follicular hyperplasia. ${ }^{8}$ Fascin is expressed consistently in Reed-Sternberg cells of classical Hodgkin lymphoma but rarely and weak in "L\&H" or "popcorn" cells of lymphocyte predominant Hodgkin lymphoma. ${ }^{2.9}$ There are few studies revealing fascin expression in a subset of diffuse large B-cell lymphomas and anaplastic large cell lymphomas. ${ }^{3,4,5}$ Taking into the consideration that some classical Hodgkin lymphomas may even express cytotoxic molecules, differential diagnosis between classical Hodgkin lymphoma and anaplastic large cell lymphoma may be challenging. ${ }^{10}$ Fascin appears to have a limited usefulness in the differential diagnosis between these two entities as its negativity may help the exclusion of classical Hodgkin lympho$\mathrm{ma}^{2.5,9}$

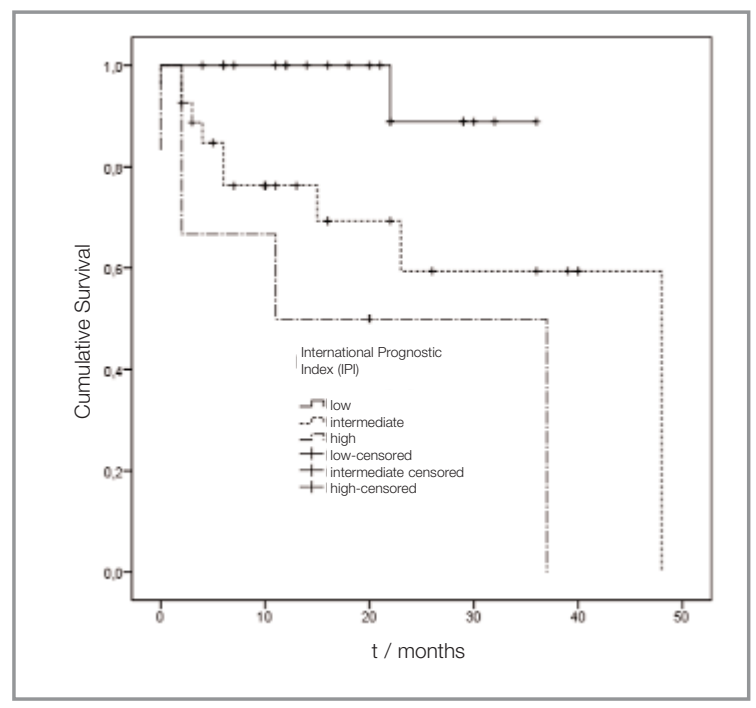

Figure 5. Graph showing relationship between IPI and survival $(p=0.006)$

Fascin staining was observed in 34 of 55 (61.8\%) DLBCLs in our study and 20 (36.3\%) of them were diffuse strong. Bakshi et al. observed staining in 6 of 41 cases (14.6\%), 1 case was weak positive, 1 case showed focal to diffuse staining and the remaining 3 were strong positive. ${ }^{2}$ Idrees et al. studied fascin in 26 DLBCLs and observed staining in 8 cases, all of which were strong (30.8\%). ${ }^{9}$ With smaller number of cases studied, Idrees et al. found nearly two folds staining more in terms of percentages than Bakshi et al. found. ${ }^{2 .}$ Our serial is the largest among the three studies on fascin expression in DLBCLs. Larger series, questioning fascin expression particularly in various histopathologic subtypes of DLBCL and comparing the rate and pattern of the staining, will add more to the literature.

International prognostic index (IPI) is considered as the dominant prognostic factor in high grade lymphomas. ${ }^{11}$ Patients with DLBCL may show highly variable clinical outcomes even if they are in the same IPI group and taking the same therapy regimen. ${ }^{6}$ Efforts to explain this heterogeneity in biological behavior, revealed some prognostic factors such as bcl-2 expression, CD5 expression, myc rearrangements, and the germinal center (GC) or nongerminal center (non-GC) origin of the tumor. ${ }^{11-15}$ Results of the studies after the addition of rituximab to the anthracyclin-based chemotherapy showed that $\mathrm{R}-\mathrm{CHOP}$ regimen overcame the negative im- 
pact of some of these prognostic factors ${ }^{7,16-19}$, while prognostic value of some (i.e. GC, non-GC phenotype) remains controversial. ${ }^{7,15}$ Double-hit and triple-hit lymphomas have had a poor response to R-CHOP therapy. ${ }^{18}$ Some markers such as beclin-1 were shown to be the predictors of favorable clinical outcome in patients treated with $\mathrm{R}-\mathrm{CHOP}^{20}$

Fascin was shown to be a poor prognostic factor in certain epithelial tumors due to its role cell adhesion, cell motility and invasiveness. ${ }^{21-23}$ However, in lymphoid malignancies, fascin expression was observed in the entities representing the two distinct ends of biological behavior spectrum. ${ }^{2,59}$

In this study, there was no statistically significant correlation between IPI score and state of fascin expression, between any component (age, stage, ECOG performance status, extranodal sites, serum LDH level) of the IPI score alone, in addition to gender, state of fascin expression, chemotherapy response, and state of fascin expression. In our study, fascin expression did not appear as a stand alone prognostic factor independent from IPI, while IPI was the dominant predictive factor of clinical outcome.

This study has failed to show any prognostic impact of fascin expression in DLBCL patients, treated with R-CHOP regimen. Studies, may be conducted to evaluate the results of fascin expression in pathological archival materials and survival data obtained from the files of DLBCL patients treated in the pre-rituximab era. Whether fascin expression in DLBCLs have a prognostic impact or not, considering the alterations seen in fascin expression from follicular hyperplasia to neoplastic follicles of follicular B-cell lymphomas, as well as its expression in neoplastic cells of distinct hematolymphoid malignancies, the role of fascin remains to be elucidated. Further studies on fascin expression may help us to understand the tumor biology of lymphomas better.

\section{REFERENCES}

1. Hashimoto Y, Kim DJ, Adams JC. The roles of fascins in health and disease. J Pathol 224: 289-300, 2011.

2. Pinkus GS, Pinkus JL, Langhoff E, et al. Fascin, a sensitive new marker for Reed-Sternberg cells of Hodgkin's disease. Evidence for a dendritic or B cell derivation? Am J Pathol 150: 543-562, 1997.
3. Bakshi NA, Finn WG, Schnitzer B, Valdez R, Ross CW. Fascin expression in diffuse large B-cell lymphoma, anaplastic large cell lymphoma, and classical Hodgkin lymphoma. Arch Pathol Lab Med 131: 742-747, 2007.

4. Idrees R, Ahmad Z, Qureshi A, et al. Is fascin really a useful marker in distinguishing between classical Hodgkin's lymphoma and various types of non-Hodgkin's lymphomas in difficult cases? J Clin Pathol 63: 571-574, 2010.

5. Fan G, Kotylo P, Neiman RS, Braziel RM. Comparison of fascin expression in anaplastic large cell lymphoma and Hodgkin disease. Am J Clin Pathol 119: 199-204, 2003.

6. Swerdlow SH, Campo E, Harris NL, Jaffe ES, et al. WHO Classification of Tumours of Haemotopoietic and Lymphoid Tissues. Lyon, France: IARC 2008.

7. Natkunam $Y$, Farinha $P$, Hsi ED, et al. LMO2 protein expression predicts survival in patients with diffuse large B-cell lymphoma treated with anthracycline-based chemotherapy with and without rituximab. J Clin Oncol 26: 447-454, 2008.

8. Said JW, Pinkus JL, Shintaku IP, et al. Alterations in fascin-expressing germinal center dendritic cells in neoplastic follicles of B-cell lymphomas. Mod Pathol 11: 1-5, 1998.

9. Bhargava P, Pantanowitz L, Pinkus GS, et al. Utility of fascin and JunB in distinguishing nodular lymphocyte predominant from classical lymphocyte-rich Hodgkin lymphoma. Appl Immunohistochem Mol Morphol 18: 16-23, 2010.

10. Asano N, Oshiro A, Matsuo K, et al. Prognostic significance of T-cell or cytotoxic molecules phenotype in classical Hodgkin's lymphoma: a clinicopathologic study. J Clin Oncol 24: 4626-4633, 2006.

11. The International Non-Hodgkin's Lymphoma Prognostic Factors Project: a predictive model for aggressive non-Hodgkin's lymphoma. N Engl J Med 329: 987994, 1993.

12. Hermine O, Haioun C, Lepage E, et al. Prognostic significance of bcl-2 protein expression in aggressive non-Hodgkin's lymphoma. Groupe d'Etude des Lymphomes de l'Adulte (GELA). Blood 87: 265-272, 1996.

13. Went P, Zimpfer A, Tzankov A, Dirnhofer S. CD5 expression in de novo diffuse large B-cell lymphomas. Ann Oncol 20: 789-790, 2009.

14. Kramer MH, Hermans J, Wijburg E, et al. Clinical relevance of BCL2, BCL6, and MYC rearrangements in diffuse large B-cell lymphoma. Blood 92: 3152-3162, 1998.

15. Nyman $\mathrm{H}$, Adde $\mathrm{M}$, Karjalainen-Lindsberg $\mathrm{ML}$, et al. Prognostic impact of immunohistochemically defined germinal center phenotype in diffuse large B-cell lymphoma patients treated with immunochemotherapy. Blood 109: 4930-4935, 2007. 
16. Mounier N, Briere J, Gisselbrecht C, et al. Groupe d'Etude des Lymphomes de l'Adulte. Estimating the impact of rituximab on bcl-2-associated resistance to CHOP in elderly patients with diffuse large B-cell lymphoma. Haematologica 91: 715-716, 2006.

17. Winter JN, Weller EA, Horning SJ, et al. Prognostic significance of Bcl-6 protein expression in DLBCL treated with $\mathrm{CHOP}$ or $\mathrm{R}-\mathrm{CHOP}$ : a prospective correlative study. Blood 107: 4207-4213, 2006.

18. Akyurek N, Uner A, Benekli M, Barista I. Prognostic significance of MYC, BCL2, and BCL6 rearrangements in patients with diffuse large B-cell lymphoma treated with cyclophosphamide, doxorubicin, vincristine, and prednisone plus rituximab. Cancer 118: 41734183, 2012.

19. Miyazaki K, Yamaguchi M, Suzuki R, et al. CD5-positive diffuse large B-cell lymphoma: a retrospective study in 337 patients treated by chemotherapy with or without rituximab. Ann Oncol 22: 1601-1607, 2011.

20. Huang JJ, Zhu YJ, Lin TY, et al. Beclin 1 expression predicts favorable clinical outcome in patients with diffuse large B-cell lymphoma treated with R-CHOP. Hum Pathol 42: 1459-1466, 2011.

21. Jawhari AU, Buda A, Jenkins M, et al. Fascin, an actin-bundling protein, modulates colonic epithelial cell invasiveness and differentiation in vitro. Am $\mathrm{J}$ Pathol 162: 69-80, 2003.

22. Pelosi G, Pastorino U, Pasini F, et al. Independent prognostic value of fascin immunoreactivity in stage I non-small cell lung cancer. $\mathrm{Br} J$ Cancer 88: 537-547, 2003.

23. Hu W, McCrea PD, Deavers M, et al. Increased expression of fascin, motility associated protein, in cell cultures derived from ovarian cancer and in borderline and carcinomatous ovarian tumors. Clin Exp Metastasis 18: 83-88, 2000.

\section{Correspondence}

Dr. Nazım Emrah KOÇER

Başkent Üniversitesi

Adana Uygulama ve Araştırma Merkezi

Patoloji Bölümü

Yüreğir, ADANA / TURKEY

Tel: (+90.322) 3272727 ext. 1157

Fax: (+90.322) 3271274

e-mail: nemrahkocer@yahoo.com 